\title{
Subchronic and Chronic Effects \\ of Feeding of Large Amounts of Acetaminophen in $\mathrm{B} 6 \mathrm{C} 3 \mathrm{~F} 1 \mathrm{Mice}$
}

\author{
Hiroyuki Amo \\ Aichi Women's College, Aichi-ken \\ Mutsushi Matsuyama \\ Laboratory of Ultrastructure Research, Aichi \\ Cancer Center Research Institute, Nagoya
}

\begin{abstract}
$N$-Acetyl- $p$-aminophenol (acetaminophen) is one of the main metabolites of acetophenetidine (phenacetin), which was proved to be a carcinogen ${ }^{1,2}$. Ishidate and Odashima have found that acetaminophen itself induced chromosomal aberrations in cultured Chinese hamster cells ${ }^{3}$. The repair test by the rec-assay also gave a positive result (Kada et al., unpublished data). These results prompted us to perform an experiment of long-term administration of acetaminophen in $\mathrm{B} 6 \mathrm{C} 3 \mathrm{~F} 1$ mice.

During the preparation of this article Flaks and Flaks have reported that acetaminophen is tumorigenic in mice of the IF strain"). The difference between results of the present study and the results obtained by Flaks and Flaks is briefly discussed.
\end{abstract}

\section{MATERIALS AND METHODS}

Six-week-old (C57BL/6 $\times \mathrm{C} 3 \mathrm{H} / \mathrm{He}$ ) F1 (B6C3F1) mice of both sexes, weighing 17-25g, were purchased from Charles River Japan Inc., Atsugi and were maintained on the basal diet (CE-2, CLEA Japan Inc., Tokyo) and tap water, until they were 8-9 weeks old when tests were started. Ten or 11 mice were housed in an aluminum cage and kept in an air-conditioned room at $24-25^{\circ} \mathrm{C}$ with $45-55 \%$ humidity. Acetaminophen (reagent grade, more than $98 \%$ pure) was mixed with the basal diet and was processed into pellets. Acetaminophen in the pellets proved to be stable after being processed and was stored for several months.

\section{Subchronic toxicity test}

Mice of 5 experimental groups, each consisting of 10 male and 10 female mice, were fed a diet containing $0.3,0.6,1.25,2.5$ or $5 \%$ of acetaminophen. Ten male and 10 female mice were fed with the basal diet as a control group. All the animals were given tap water freely. They were weighed once a week during the lst month and later once a month, and the average daily food consumption was recorded throughout the experimental period. The survivors were killed 41 weeks following the commencement of the experiment.

\section{Chronic toxicity test}

One hundred and five male and 105 female $\mathrm{B} 6 \mathrm{C} 3 \mathrm{~F} 1$ mice were maintained on a diet containing 0.3 or $0.6 \%$ acetaminophen. Fifty male and 50 female mice were maintained on the basal diet. All the animals were given tap water freely. The survivors were killed after 134 weeks. All dead or sacrificed animals were necropsied. The liver, lungs, spleen, pancreas, kidneys, stomach, small and large intestines, heart, urinary bladder, thymus, adrenals, thyroid, brain, pituitary, testes, ovaries, and tumors were fixed in $10 \%$ formalin solution, embedded in paraffin, sectioned at $5 \mu$, and stained routinely with hematoxylin 
and eosin for histologic examination.

\section{RESULTS}

Subchronic toxicity test

In the groups with $5,2.5$, and $1.25 \%$ diets, mice showed marked weight loss immediately after the commencement of the treatment, but mice of the groups with 0.6 and $0.3 \%$ diets had normal weight gain just as those of the control group during the experiment (Fig. 1). All the mice of the $5 \%$ diet group died within 2 weeks and almost all the mice of the $2.5 \%$ diet group died within 10 weeks of myocardial infarction and/or hemorrhagic enteritis (Fig. 2). All mice, except 1, of the groups with the 1.25, 0.6, and $0.3 \%$ diets survived for 13 weeks, but all the mice of the $1.25 \%$ diet group developed liver fibrosis 41
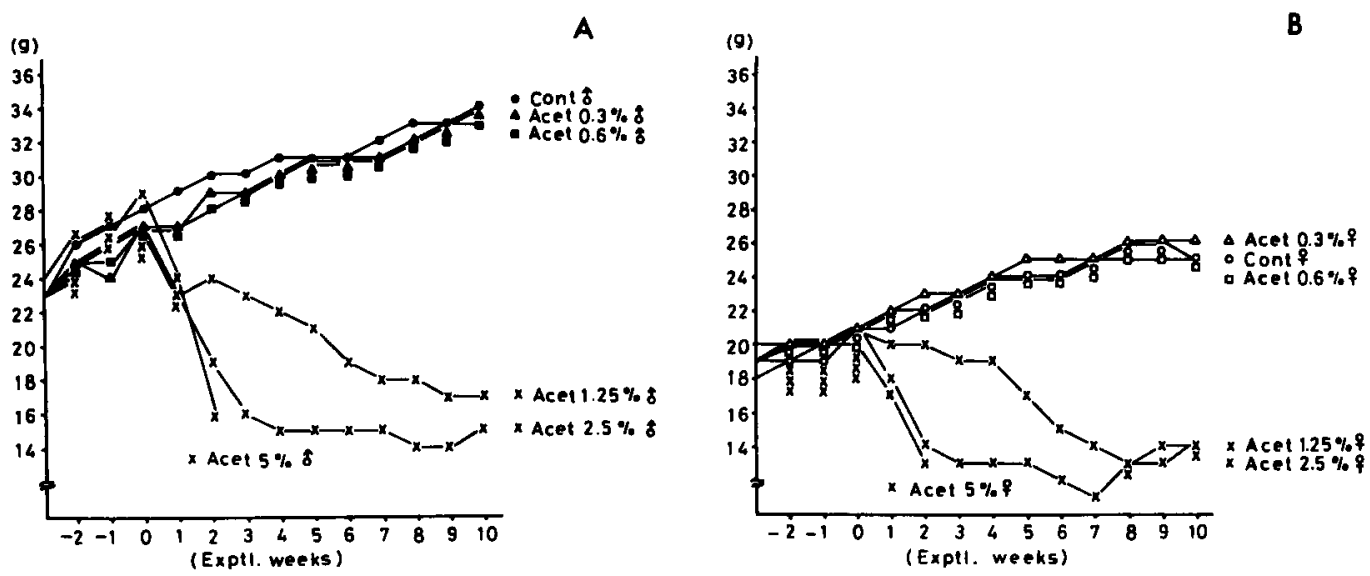

Fig. 1 Average body weight in male (A) and female (B) mice, which were fed a diet containing $0.3,0.6$,

$1.25,2.5$ or $5 \%$ acetaminophen or the basal diet.

A

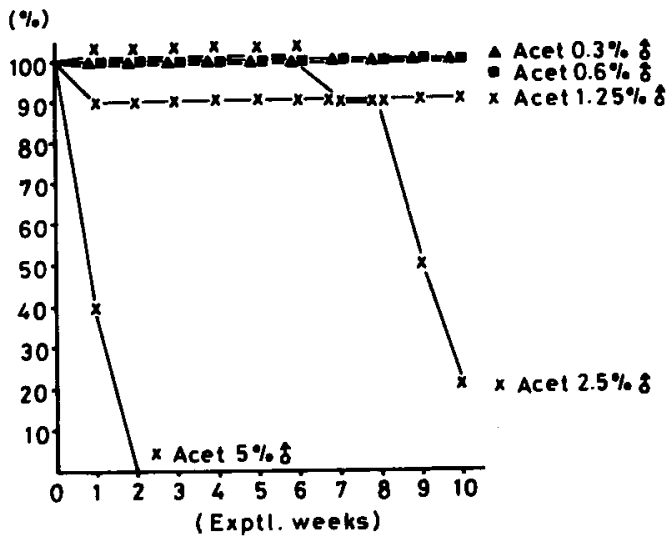

B

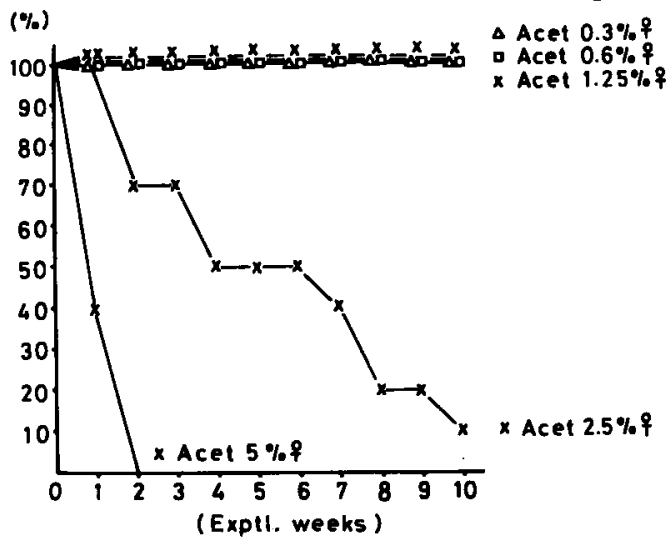

Fig. 2 Survival rates in male (A) and female (B) mice, which were fed a diet containing $0.3,0.6,1.25,2.5$ or $5 \%$ acetaminophen or the basal diet. 
weeks after commencement (Fig. 3). The livers of the latter group of mice weighed around $0.9 \mathrm{~g}$ in the males and around $0.8 \mathrm{~g}$ in the females (compared to around $2.3 \mathrm{~g}$ in the control males and around 1.8 $\mathrm{g}$ in the control females). Histologically, necrosis and necrobiosis of parenchymal cells in the peripheral zones of the lobules were prominent. Moderate fibrosis was found in the portal triads associated with

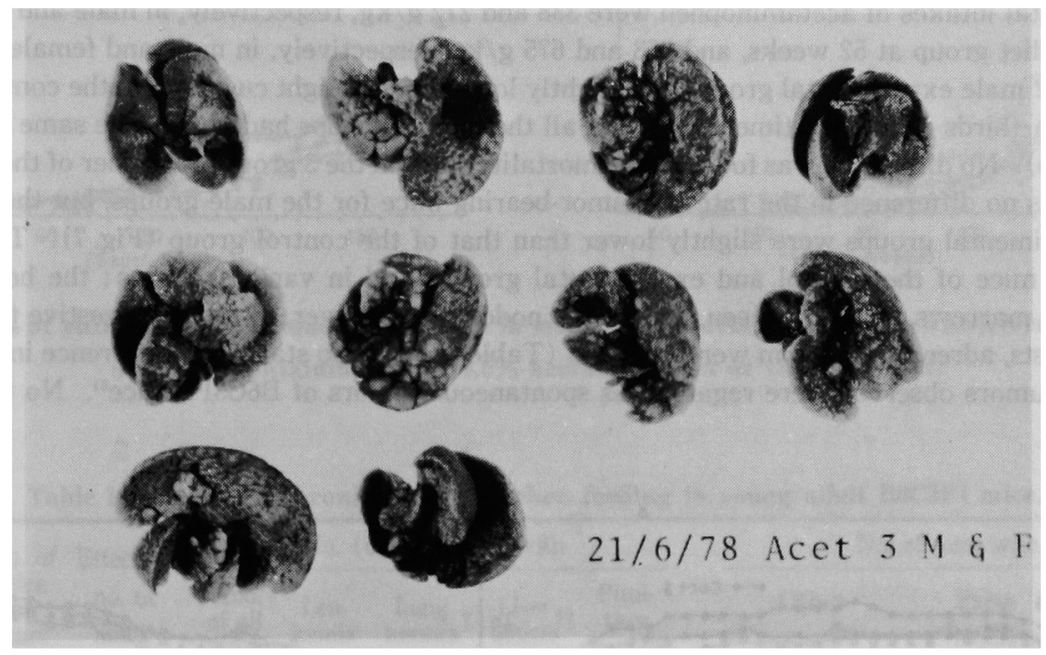

Fig. 3 Livers of male and female mice treated with $1.25 \%$ diet of acetaminophen, showing coarsely granular surface.

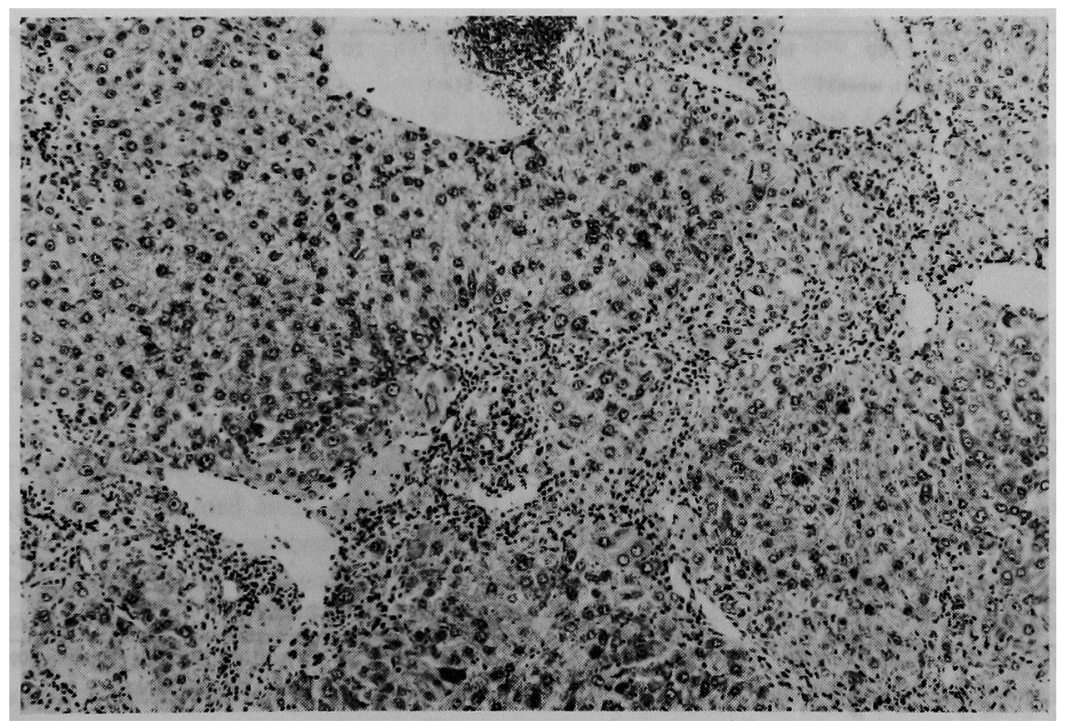

Fig. 4 Micrograph of a liver of a male mouse which was fed a diet containing $1.25 \%$ acetaminophen, showing fibrosis in the portal triads and pseudolobules. H-E. $\times 90$ 
moderate infiltration of lymphocytes and granulocytes, forming pseudolobules (Fig. 4). Many hemosiderin-laden macrophages were noticed in the triads. From these results the maximum tolerated dose by oral feeding to young adult $\mathrm{B} 6 \mathrm{C} 3 \mathrm{~F} 1$ mice on the chronic toxicity test was determined to be the $0.6 \%$ diet.

\section{Chronic toxicity test}

There was no remarkable difference in food intake between the experimental and control groups. Calculated total intakes of acetaminophen were 338 and $272 \mathrm{~g} / \mathrm{kg}$, respectively, in male and female mice of the $0.6 \%$ diet group at 52 weeks, and 863 and $675 \mathrm{~g} / \mathrm{kg}$, respectively, in male and female mice at 133 weeks. The 2 male experimental groups had slightly lower body-weight curves than the control group in the latter two-thirds of the test time period, but all the female groups had almost the same body-weight curves (Fig. 5). No difference was found in the mortality rates in the 3 groups for either of the sexes (Fig. 6). There was no difference in the rates of tumor-bearing mice for the male groups, but those for the 2 female experimental groups were slightly lower than that of the control group (Fig. 7). Tumors were found in the mice of the control and experimental groups, and in various organs: the hematopoietic tissues (bone marrows, thymus, spleen, and lymph nodes), lungs, liver, pituitary, digestive tract, uterus, ovaries, breasts, adrenals, and skin were involved (Table 1), with no statistical difference in the incidences. These tumors observed were regarded as spontaneous tumors of $\mathrm{B} 6 \mathrm{C} 3 \mathrm{~F} 1$ mice $^{51}$. No tumors were
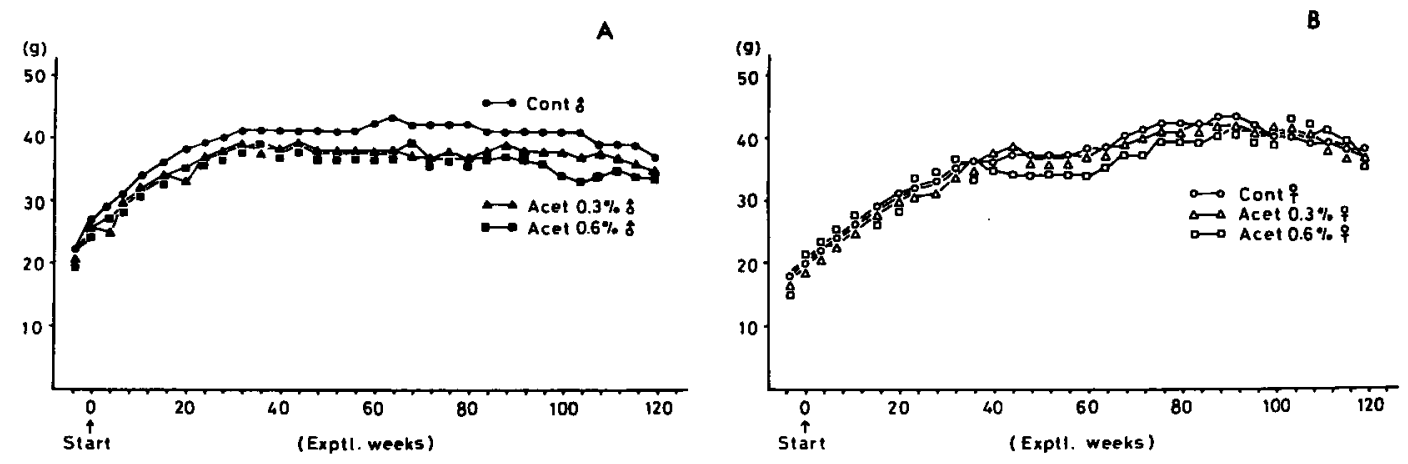

Fig. 5 Average body weight in male (A) and female (B) mice, which were maintained on a diet containing 0.3 or $0.6 \%$ acetaminophen or the basal diet.
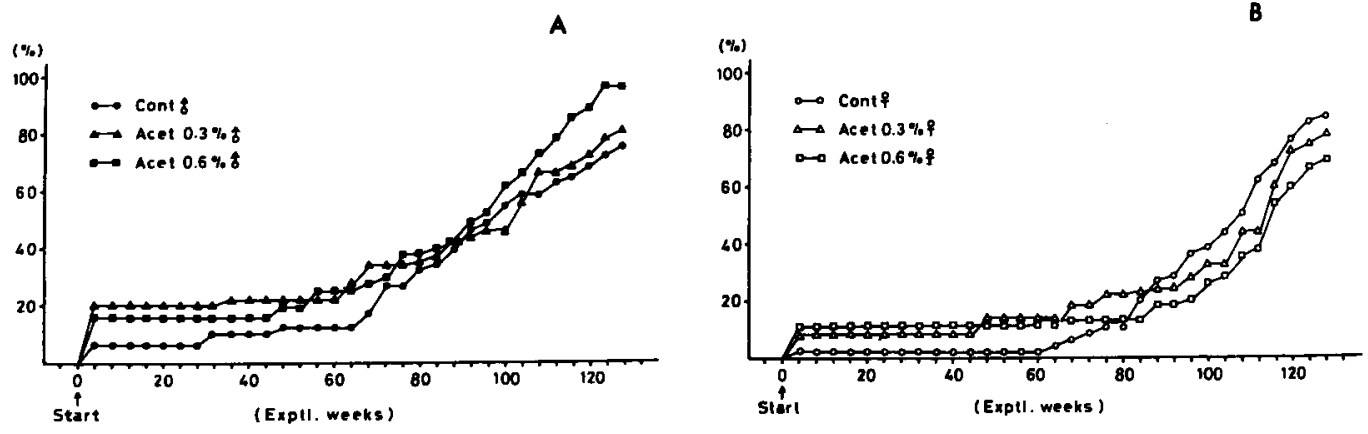

Fig. 6 Mortality rates in male (A) and female (B) mice, which were maintained on a diet containing 0.3 or $0.6 \%$ acetaminophen or the basal diet. 

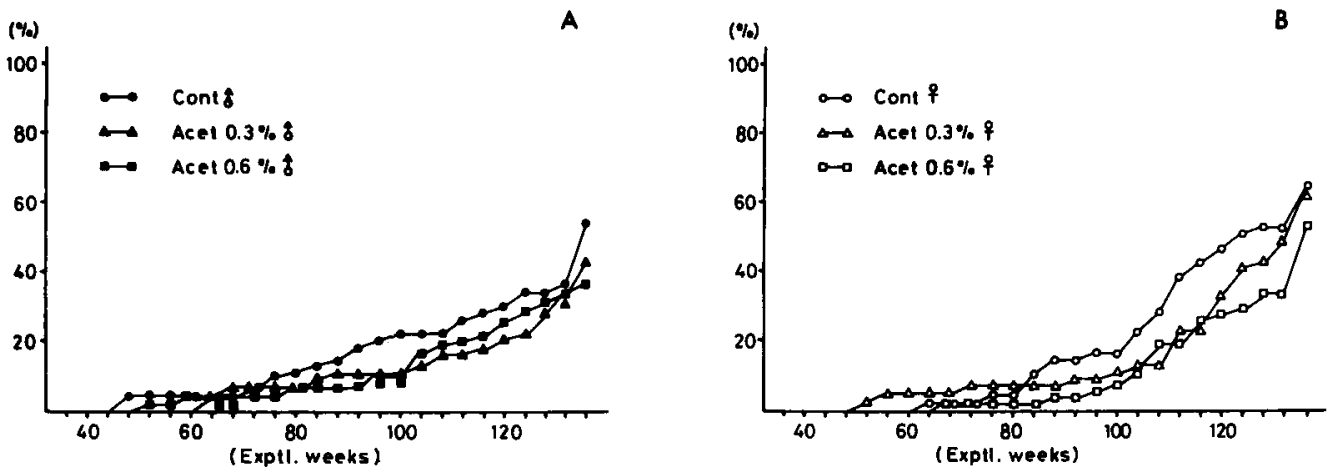

Fig. 7 Rates of animals bearing tumors in all sites in male $(A)$ and female (B) mice, which were maintained on a diet containing 0.3 or $0.6 \%$ acetaminophen or the basal diet.

Table 1 Effects of chronic acetaminophen feeding in young adult B6C3F1 mice.

\begin{tabular}{|c|c|c|c|c|c|c|c|c|c|c|c|c|c|c|}
\hline \multirow[b]{2}{*}{ Sex } & \multirow{2}{*}{$\begin{array}{l}\text { Treat- } \\
\text { ment }\end{array}$} & \multirow{2}{*}{$\begin{array}{l}\text { No. of } \\
\text { mice } \\
\text { at } \\
\text { start }\end{array}$} & \multirow{2}{*}{$\begin{array}{c}\text { Effective } \\
\text { no. of } \\
\text { mice }\end{array}$} & \multicolumn{5}{|c|}{ No. $(\& \%)$ of mice with } & \multicolumn{6}{|c|}{ No. of mice with } \\
\hline & & & & $\begin{array}{l}\text { Tumors } \\
\text { of all } \\
\text { sites }\end{array}$ & Leu- & $\underset{\text { tumors }}{\text { Lung }} \dagger$ & $\underset{\text { tumors }}{\text { Liver }}$ & $\begin{array}{c}\text { Pitui- } \\
\text { tary } \\
\text { adenoma }\end{array}$ & & $\begin{array}{l}\text { Other } \\
\text { umors* }\end{array}$ & & $\begin{array}{l}\text { Pneu- } \\
\text { monia }\end{array}$ & $\begin{array}{l}\text { Ente- } \\
\text { ritis }\end{array}$ & $\begin{array}{l}\text { Miscel- } \\
\text { laneous } \\
\text { diseases }\end{array}$ \\
\hline $\mathbf{M}$ & $\begin{array}{c}\text { Basal } \\
\text { diet }\end{array}$ & 50 & 43 & $27(63)$ & $5(12)$ & $5(12)$ & $13(30)$ & $0(0)$ & $\begin{array}{l}1 \mathrm{fsh} \\
1 \mathrm{fsb} \\
1 \text { pha }\end{array}$ & $\begin{array}{l}1 \mathrm{fih} \\
1 \mathrm{msb}\end{array}$ & $\begin{array}{l}2 \mathrm{msh} \\
2 \mathrm{hem}\end{array}$ & 11 & 0 & 6 \\
\hline $\mathbf{M}$ & $\begin{array}{c}0.3 \% \\
\text { diet }\end{array}$ & 50 & 39 & $21(54)$ & $5(13)$ & $3(8)$ & $12(31)$ & $1(3)$ & $\begin{array}{l}1 \mathrm{fsb} \\
1 \mathrm{msh}\end{array}$ & $\begin{array}{l}3 \mathrm{msb} \\
1 \mathrm{osd}\end{array}$ & 1 hem & 10 & 4 & 4 \\
\hline $\mathbf{M}$ & $\begin{array}{c}0.6 \% \\
\text { diet }\end{array}$ & 55 & 45 & $23(51)$ & $7(16)$ & $2(4)$ & $6(13)$ & $1(2)$ & $\begin{array}{l}1 \mathrm{msh} \\
1 \mathrm{fsb}\end{array}$ & $\begin{array}{l}2 \text { hem } \\
1 \mathrm{msb}\end{array}$ & $1 \mathrm{cbs}$ & 10 & 5 & 11 \\
\hline $\mathbf{F}$ & $\begin{array}{c}\text { Basal } \\
\text { diet }\end{array}$ & 50 & 49 & $32(65)$ & $20(41)$ & $3(6)$ & $2(4)$ & $2(4)$ & $\begin{array}{l}2 \text { bsu } \\
1 \text { ova } \\
1 \text { ada }\end{array}$ & $\begin{array}{l}2 \text { amg } \\
2 \text { gct }\end{array}$ & $\begin{array}{l}3 \mathrm{hem} \\
2 \mathrm{msc}\end{array}$ & 12 & 1 & 5 \\
\hline $\mathbf{F}$ & $\begin{array}{c}0.3 \% \\
\text { diet }\end{array}$ & 50 & 46 & $33(72)$ & $24(52)$ & $1(2)$ & $2(4)$ & $3(7)$ & $\begin{array}{l}1 \mathrm{msc} \\
2 \mathrm{bsu} \\
1 \text { hes } \\
1 \mathrm{osc}\end{array}$ & $\begin{array}{l}1 \text { oss } \\
1 \text { aac } \\
1 \text { fsc }\end{array}$ & $\begin{array}{l}2 \text { skc } \\
2 \text { hem } \\
1 \text { tha }\end{array}$ & 8 & 1 & 4 \\
\hline $\mathbf{F}$ & $\begin{array}{c}0.6 \% \\
\text { diet }\end{array}$ & 55 & 50 & $33(66)$ & $20(40)$ & $1(2)$ & $8(16)$ & $9(18)$ & $\begin{array}{l}1 \mathrm{cmg} \\
1 \text { aro }\end{array}$ & $\begin{array}{l}1 \text { amg } \\
2 \text { tha }\end{array}$ & 1 bsu & 11 & 4 & 6 \\
\hline
\end{tabular}

- Survived more than 51 weeks, when the 1st neoplasm was found. $†$ Contained lung adenoma and carcinoma. If Contained liver adenoma and carcinoma. ** fsh = fibrosarcoma of hip, fih = fibroma of hip, $\mathrm{msh}=$ myosarcoma of hip, $\mathrm{fsb}=$ fibrosarcoma of back, $\mathrm{msb}=$ myosarcoma of back, hem $=$ hemangioma, pha $=$ pheochromocytoma of adrenal, osd = osteosarcoma of duodenum, cbs = carcinoma of back skin, bsu = botryoid sarcoma of uterus, amg = adenoma of mammary gland, ova = ovarian adenoma, get $=$ granulosa cell tumor of ovary, $\mathrm{msc}=$ myosarcoma of chest wall, ada $=$ adrenal adenoma, oss = osteogenic sarcoma of spinal column, skc $=$ skin carcinoma, aac = adenoma of adrenal cortex, hes = hemangiosarcoma, fsc = fibrosarcoma of chest wall, tha = thyroid adenoma, osc = osteosarcoma of chest wall, $\mathrm{cmg}=$ carcinoma of mammary gland, aro = adrenal rest tumor of ovary. \# Including urethritis, cystitis, gastrointestinal bleeding, liver abscess, pyometra, and skin ulcer. 
found in the nasal cavity or urinary passage. Some of the mice in each group died of pneumonia, enteritis and other miscellaneous diseases (Table 1).

\section{DISCUSSION}

The results of the present tests show that feeding the maximum tolerated dose of acetaminophen $(0.6$ $\%$ diet) held no carcinogenic hazard for $\mathrm{B} 6 \mathrm{C} 3 \mathrm{~F} 1$ mice. Hiraga et al. also showed that 0.9 and $1.3 \%$ diets of acetaminophen administered to Fischer 344 rats did not induce tumors at statistically higher rates (unpublished data). However, Flaks and Flaks fed IF mice with the diet containing $1.0 \%$ acetaminophen and have shown that 20 out of 23 male mice which survived for 78 weeks developed liver tumors ${ }^{4}$. It was also shown that their dose was too high for a long term test, because 32 out of 60 male mice died of liver necrosis usually within 2 days after the commencement of the treatment. On the other hand, all of the B6C3F1 mice treated with the $1.2 \%$ diet developed liver fibrosis, but not liver tumors, after 41 weeks in the present study. Currently it is not known whether the discrepancy on tumorigenesis between these studies is due to the different strain of mice used or the purity of the-compound.

Phenacetin has been reported to be a carcinogen in man, rats and mice, inducing urothelial tumors of the renal pelvis and tumors in the nasal cavity ${ }^{1,2,6-9)}$. On the other hand, acetaminophen, which is the major metabolite of phenacetin ${ }^{10,11}$, induced no urothelial tumors nor tumors in the nasal cavity in rats nor mice. These findings suggest that hydroxylated metabolites, not acetaminophen, of phenacetin may be proximal mutagens and carcinogens, as assumed by many studies ${ }^{12-14}$.

In the chronic toxicity test, the daily dosage of acetaminophen used was about 12 to 24 times larger than human regular dosage in Japanese Pharmacopoeia. Papillary necrosis of the renal pelvis was a prominent feature in patients with phenacetin abuse for an average of 17 years"). The papillary necrosis and papillary hyperplasia are assumed to be precursors of renal pelvic tumors ${ }^{15,16}$. However, acetaminophen induced neither papillary necrosis nor papillary hyperplasia in mice in the present tests.

Acetaminophen is rapidly conjugated with glucuronate by the liver and excreted by the kidney ${ }^{10)}$. Gastrointestinal hemorrhage, hepatic necrosis, renal necrosis, and cardiac myotonia were induced in man and rats, as acute toxicities of acetaminophen ${ }^{17,28}$. The present test also showed acetaminophen induced liver fibrosis in mice as a subchronic toxicity.

\section{SUMMARY}

Subchronic and chronic effects of acetaminophen were examined, using B6C3F1 mice orally administered with $0.3,0.6$, and $1.25 \%$ acetaminophen diets daily. All of the mice treated with a $1.25 \%$ diet developed liver fibrosis after 41 weeks. Mice in the experimental groups treated with 0.3 and $0.6 \%$ diets for 52-135 weeks, as well as mice in the control group treated with the basal diet, developed various tumors, but no difference in tumor incidence was detected among these groups.

\section{REFERENCES}

1) Isaka, H., Yoshii, H., Otsuji, A., Koike, M., Nagai, Y., Koura, M., Sugiyasu, K. and Kanabayashi, T. : Tumors of Sprague-Dawley rats induced by long-term feeding of phenacetin, Gann, 70, 29-36 (1979).

2) Nakanishi, K., Kurata, Y., Oshima, M., Fukushima, S. and Ito, N. : Carcinogenicity of phenacetin : Long-term feeding study in B6C3Fl mice, Int. J. Cancer, 29, 439-444 (1982).

3) Ishidate, M. Jr. and Odashima, S. : Chromosome tests with 134 compounds on Chinese hamster cells in vitro -a screening for chemical carcinogens, Mutat. Res., 48, 337-354 (1977).

4) Flaks, A. and Flaks, B. : Induction of liver cell tumours in IF mice by paracetamol, Carcinogenesis, 4, 363368 (1983).

5) Ward, J.M., Goodman, D.G., Squire, R.A., Chu, K.C. and Linhart, M.S. : Neoplastic and nonneoplastic lesions in (C57BL/6N $\times$ C3H/HeN) F1 (B6C3F1) mice, J. Natl. Cancer Inst., 63, 849-854 (1979).

6) Bengtsson, U., Angervall, L., Ekman, H. and Lehmann, L. : Transitional cell tumors of the renal pelvis in analgesic abusers, Scand. J. Urol. Nephrol., 2, 145-150 (1968).

7) Angervall, L., Bengtsson, U., Zetterlund, C.G. and Zsigmond, M. : Renal pelvic carcinoma in a Swedish district with abuse of a phenacetin-containing drug, Brit. J. Urol., 41, 401-405 (1969). 
8) Taylor, J.S. : Carcinoma of the urinary tract and analgesic abuse, Med. J. Aust., 59, 407-409 (1972).

9) Johansson, S., Angervall, L., Bengtsson, U. and Wahlqvist, L. : Uroepithelial tumors of the renal pelvis associated with abuse of phenacetin-containing analgesics, Cancer, 33, 743-753 (1974).

10) Brodie, B.B. and Axelrod, J.: The fate of acetophenetidin (phenacetin) in man and methods for the estimation of acetophenetidin and its metabolites in biological material, J. Pharmacol. Exptl. Therap., 97, 58-67 (1949).

11) Nery, R.: Some new aspects of the metabolism of phenacetin in the rat, Biochem. J., 122, 317-326 (1971).

12) Nery, R.: The possible role of $\mathrm{N}$-hydroxylation in the biological effects of phenacetin, Xenobiotica, 1, 339343 (1971).

13) Calder, I.C., Goss, D.E., Williams, P.J., Funder, C.C., Green, C.R., Ham, K.N. and Tange, J.D. : Neoplasia in the rat induced by $\mathrm{N}$-hydroxyphenacetin, a metabolite of phenacetin, Pathology, 8, 1-6 (1976).

14) Shudo, K., Ohta, T., Orihara, Y., Okamoto, T., Nagao, M., Takahashi, Y. and Sugimura, T.: Chemical reactivity and mutagenicity of $\mathrm{N}-\mathrm{OH}$-phenacetin, Proc. Jpn. Cancer Assoc., 37th Annu. Meet., 44 (1978) (Japanese).

15) Johansson, S. and Angervall, L. : Urothelial hyperplasia in female Sprague-Dawley rats induced by long term feeding of phenacetin, Acta. Path. Microbiol. Scand., Sect. A, 84, 353-354 (1976).

16) Johansson, S. and Angervall, L.: Urothelial changes of the renal papillae in Sprague-Dawley rats induced by long term feeding of phenacetin, Acta. Pathol. Microbiol. Scand. Sect., A, 84, 375-383 (1976).

17) Boyd, E. and Bereczky, G : Liver necrosis from paracetamol, Brit. J. Pharmacol., 26, 606-614 (1966).

18) Boyer, T.D. and Rouff, S.L.: Acetaminophen-induced hepatic necrosis and renal failure, J. Amer. Med. Assoc., 218, 440-441 (1971).

\title{
B6C3F1 マウスにおけるアセトアミノ \\ フェンの長期経口投与の影響
}

\author{
愛知女子短期大学 \\ 天 羽弘行 \\ 䛵知県がんセンター研究所超微形態部 \\ 松山睦司
}

アセトアミノフェンは解熱，鎮痛剤として広く用いられている。しかし最近フェナセチンに癌原性がみいだされたた め, その主なる代謝産物であるアセトアミノフェンについても癌原性の検索が必要となった。既にアセトアミノフェン の変異原性についての满索が行われ, Ames test $(-)$, repair test $(-)$, chromosome test (-), Silkworm test (-) の成績が得られている。このような現状に鑑み,アセトアミノフェンの亜慢性毒性および癌原性の有無を明らかにする 目的で本研究を行った。

アセトアミノフェンの 5，2.5，1.25，0.6および0.3\%混合飼料を (C57BL/6×C3H/He) F1 (B6C3F1) マウスに経 口投与したところ， 5 および2.5\%投与群マウスの大多数は10週間以内に心筋梗塞あるいは肝䐬萎縮で死亡した。1.25\% 投与群では41週後の屠殺時全例に肝線維症が認められた。

この亜慢性実験の結果からアセトアミノフェンの最大耐量を $0.6 \%$ 混合飼料と決定し, $0.6 \%$ おびその半量の $0.3 \%$ 混 合咱料を蜼雄の B6C3F1 マウスに自由に摄取させ, 136週間飼育観察した。体重曲線, 飼料捸取量, 死亡率, 腫㾺発生率, 重㾺発生期間のいずれについても投与群と対照群の間に有意差は認められなかった。これらの結果から，アセトアミノ フェンは B6C3F1 マウスに対し癌原性を持たないものと決論した。

この詥文作成中に, Flaks および Flaksがアセトアミノフェンに造腫瘖性があると報告したので, 彼等の実験結果と 本研究の実験結果の相違について若千の考按を加えた。 
Key words : Acetaminophen, Long-term feeding, Subchronic effect アセトアミノフェン, 長期経口投与, 亜慢性効果 